\title{
The Urgency of Environment Special Court to Enforce Environment Law
}

\author{
Aju Putrijanti ${ }^{1 *}$ \\ ${ }^{1}$ Faculty of Law, Universitas Diponegoro, Semarang, Central Java
}

\begin{abstract}
The massive damage to the environment brings loss for society. Meanwhile, development is essential. Act Number 32 the Year 2009 of Protection and Management of Environment regulates the law enforcement in private, penal and administrative law. Law enforcement in environmental cases, some are difficult to implement. This is legal research that uses the secondary data of journals, regulations, judge verdicts, and explanations to use descriptive analysis. Law enforcement is influenced by the environmental system of law consist of structure, substance and culture of law. The environment disputes file to general and administrative court with special regulations because it has to be held in line with other cases and takes more time to proceed. Law enforcement of judge verdict in environment disputes is difficult to implement, because the losing party disobedience to apply. The disobedience factor influences conservation and protection, which is needed by the society affects environmental damage, making regulation of sanctions given to losing party are less power. The high number of environmental disputes needs special environment courts to investigate faster, so there will be a mechanism to supervise law enforcement. Environment special court will only investigate environment disputes and does not interrupt with other cases, and it is expected that the judge will process it immediately.
\end{abstract}

\section{Introduction}

Indonesia is a State Law as stated in Article Number 1 Paragraph 3 Constitution of 1945, and protect human rights, including rights to have a healthy environment and life, which is stated in Article $28 \mathrm{H}$. State have an obligation to give protection to the citizen for the fulfilment rights of the citizen. Besides, the state also has to develop infrastructures for progress and development. Massive development is needed, but on the other side, it can ruin the environment and endanger society. Environment decay which could happen is such as landslides, floods, increase of geothermal, drought and many forms caused by the decay.

Act Number 32 the Year 2009 of Protection and Management of Environment (hereinafter is Environmental Act) gives important points that development should be implemented based on sustainable development and environment insight, also gives regulation of law enforcement which is carried out in private, penal and administrative law.

* Corresponding author: aputriyanti@yahoo.com 
Indonesian system of law, not formally known citizen lawsuit as a mechanism to file a lawsuit in administrative environment lawsuit either civil action, this is harm to rights to have a good and healthy environment. Citizen lawsuit was settled in the general court, while based on research result by Abdul Fatah stated since citizen lawsuit as a mechanism to fulfil human rights and constitutional rights, it should become competence of Constitutional Court to settle [1]. He said that a civil lawsuit is the negligence of the government to fulfil citizen constitutional and human rights, whereas there was a civil lawsuit settled by the General Court, which is under the Supreme Court authority.

Under Supreme Court authority there are 4 (four) courts, i.e. General Court, Religion Court, Military Court and Administrative Court, and each have absolute competence. Environment disputes goes to General Court and Administrative Court, with difference requirements. There are 3 (three) obstacles to use citizen lawsuit in environmental disputes, first the absence of regulations to implement citizen lawsuit in Indonesian judiciary system, second is lack of understanding of law enforcement officer especially judge about citizen lawsuit, third is lack of environmental certified judges [2]. Law enforcement in administrative law is difficult to enforced, because of the lack of legal obedience of Defendant, this is related to culture of law.

As proposed by Muhar June and Moh Husain, the urgency to build an environmental court, first because the special environmental court will guarantee the fulfilment rights of protection and law enforcement for society, while unsolved cases can be done by a judge which has environmental knowledge quite well besides certified judge. Second, environment disputes have special characteristic, i.e. as constitutional rights, also as structural cases, besides it depends on the political will of government and House of Representatives to build an environmental court [3].

Environmental Act had regulated types of a lawsuit which can be made to protect the right of an environment of citizen and keep the environment can be used for next generation. There are no regulations about citizen lawsuits to put to Administrative Court (hereinafter is Court), as one mechanism to access to justice especially procedural justice for the environment. Previous research by Rizky Ramadhani Kurniawan stated that there should be harmonization against the Constitution of 1945 as the ground norm and Environmental Act as an umbrella act to put citizen lawsuits as procedural justice [4].

This research emphasizes making the environmental court a special court under court since administrative law enforcement of environmental disputes becomes a problem when Defendant does not want to obey the judicial verdict. Law enforcement in a civil action and criminal charges may not be as difficult as law enforcement in administrative dispute because they have an execution body to execute and supervise the implementation of judge verdict. Rights to sue in environmental disputes is restricted because there are no regulations about citizen lawsuits put into court since usually put into General Court whether private either criminal charges.

The novelty of this research is to make an environmental court as a special court under Court with developed administrative penal law as law enforcement and make new regulations of environment protection and management by adding citizen lawsuits as a mechanism to get procedural justice.

The article aims to know first how is administrative law enforcement in environmental disputes, and second, how is the development of citizen lawsuits in environment protection? This article illustrates the urgency of developing the environmental court due to damage of environment and adding access to justice as one mechanism to protect the right of a healthy environment. 


\section{Method}

This research uses normative juridical methods, which comprises of a comparative approach, statute approach. The primary data used are regulations, and secondary data are expert opinions, articles, and related references. Data will be analysed qualitatively and described by descriptive analysis.

\section{Discussion}

\subsection{Future Environmental Special Court to Settle Environment Disputes.}

Referring to Lawrence Friedman's theory, effective law enforcement can be analysed into 3 (three) parts like structure, substance and culture of law [5]. Law enforcement, besides implementation of regulations, also implementation of judge verdict. Besides going to Court, environmental disputes can also be put to General Court and divided into civil Court and criminal charges while each has different characteristics to apply. Differences come from the justice system of a civil action, criminal charges and administrative.

In Germany, environmental disputes go to civil, criminal court, administrative court and European Court of Justice. Regulation of environmental pertains to administrative law, including permit, order and other administrative decisions issued by authorities, and also competent for judicial review of contractual agreement with the authorities. When regulations are governed by civil law, the civil courts have jurisdiction. With regard to administrative offences, the company is liable for environmental offences, and managers are not only liable for their own infringements but also for employee violation if they fail to supervise them. The Federal Administrative Court is an appeal instance. They only review and correct application of the laws [6].

In Sweden, there are five regional environmental courts, and the environmental court of appeal is the one superior environmental court. Environmental courts have legal jurisdiction over both land use and environment, incorporating civil and administrative matters, not including criminal powers. A hearing process in the Environmental Court of Appeal takes place in the conference room and testimony is taken informally at the conference table. The courts normally come to the site of dispute, while people are allowed to give comments directly and also represent themselves without attorneys. Based on Ulf Bjällås 's experiences, stated that an open and user-friendly hearing is an example of good environmental governance that give access to justice. People are feeling grateful and thankful since the court come to the site to look and listen and argue for what they think is right [7].

In comparison in China, since 2016, centralized jurisdiction of civil, criminal and administrative cases has gained popularity, also involving the competent department. By the end of 2018, courts adopted the " two- in-one " or " three-in-one " centralized model for criminal, civil and administrative cases for environmental disputes [8].

By comparing environmental courts in some countries, it is possible to build an environmental court, especially with regard to different conditions for each country. The future environmental court will be building an environment court justice system, starting from regulations, infrastructure as a structure of law, procedure, the parties, type of lawsuit as a substance of the law, the socio-culture of citizen, behaviour to obey the judge verdict as a culture of law. The consideration to build environmental court as a special court under Court, because take precedence is a cancellation of government decision as an object of dispute, expected there would be no further action to execute the government decision. Lack of obedience of government officer or body to execute the judge verdict will give 
sentence administrative penal so does the legal entity as the defendant intervened. The public prosecutor will supervise the execution of the judge verdict.

Chief of Supreme Court issued decree Number 134/ KMA/SK/IX/ 2011 about Environment Judge Certification regulates that to investigate the environmental case or dispute whether in general or administrative court should be held by environment certified judge to increase the handling effectivity of environment disputes as an effort to protect the environment and to fulfil justice. A judge has an important role in keeping the environment healthy by cancelling the regulation. This regulation has to synchronize to related regulations in order to avoid a legal gap in future.

Table 1. Justice system of civil action, criminal charges and administrative.

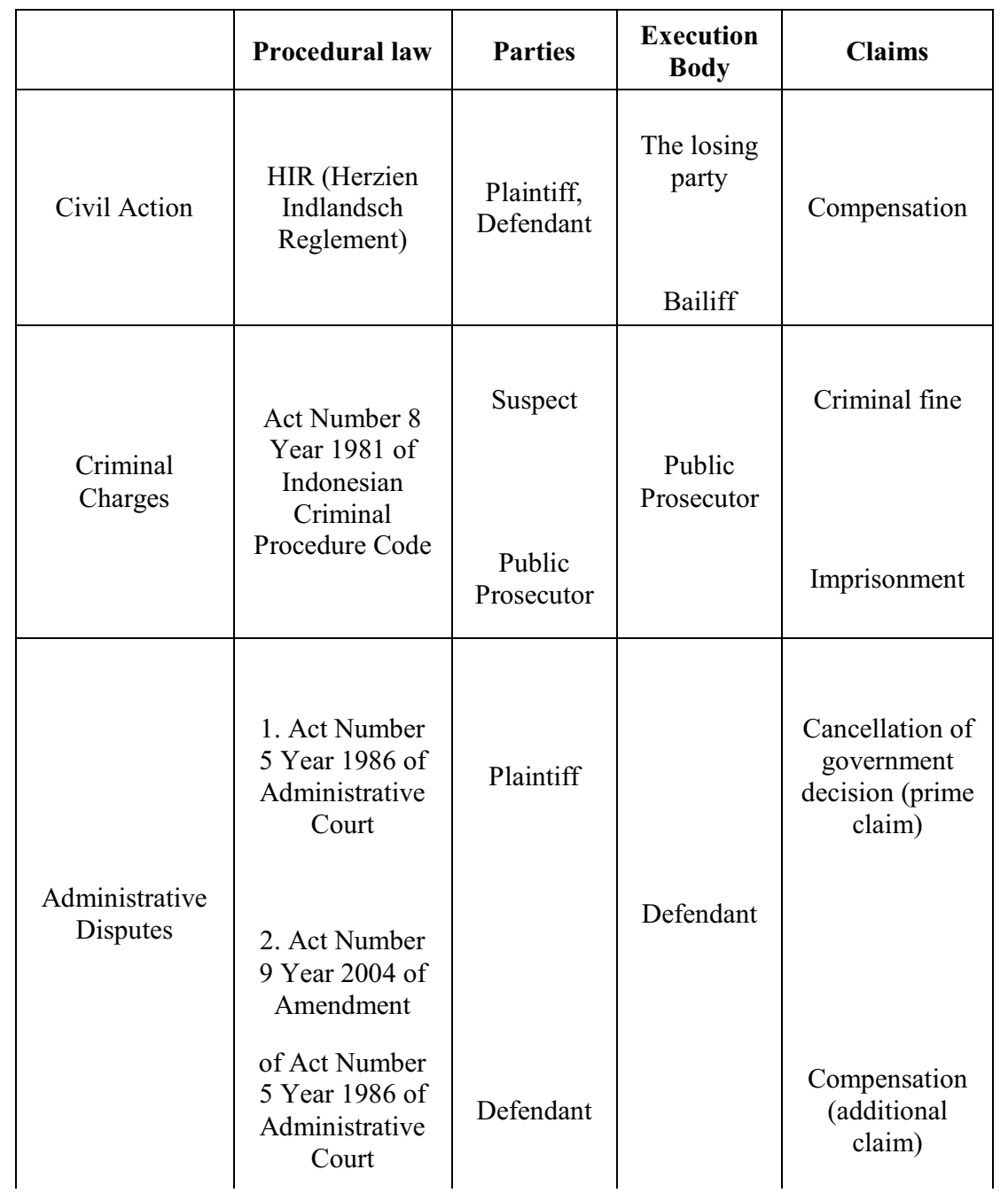




\begin{tabular}{|c|c|l|l|l|}
\hline & 3. Act Number & & \\
51 Year 2009 of & & & \\
Second & & & \\
Amendment of & & & \\
Act Number 5 & & & \\
Year 1986 of & & & \\
Administrative & & & \\
Court & & & \\
\hline
\end{tabular}

The above table shows regulations between civil, criminal charges and administrative disputes, which have different procedural laws, parties, execution body and claims. Differences make it difficult for law enforcement in court, since there is no execution body to supervise the implementation of judge verdict.

The structure of law starts from clear regulations to give legal certainty and avoid a legal gap in future. This regulates the justice system of future environmental court and government bodies to enforce the environmental law, also the infrastructure to support the whole system.

Structure of law starts from clear regulations to give legal certainty and avoid legal gap in future. This regulates about the justice system of future environmental court and government bodies to enforced the environmental law, also infrastructure to support the whole system.

Based on Article Number 27 of Act Number 48 the Year 2009 of Judiciary System, that specialized court can only perform inside one of judiciary body under Supreme Court, i.e. general court, religion court, military court and administrative court. While the establishment of the special court should be based on regulations. It is possible to make the environmental court a specialized court under court considering the damage to the environment.

Table 2. Number of cases of environment disputes in administrative Court.

\begin{tabular}{|c|c|c|c|c|c|}
\hline & $\mathbf{2 0 1 6}$ & $\mathbf{2 0 1 7}$ & $\mathbf{2 0 1 8}$ & $\mathbf{2 0 1 9}$ & $\mathbf{2 0 2 0}$ \\
\hline $\begin{array}{c}\text { Court of } \\
\text { Jakarta }\end{array}$ & 3 & 14 & 13 & 5 \\
\hline $\begin{array}{c}\text { Court of } \\
\text { Surabaya }\end{array}$ & 1 & 2 & 1 & 1 & 1 \\
\hline $\begin{array}{c}\text { Court of } \\
\text { Pekanbaru }\end{array}$ & 2 & 1 & 2 & & 2 \\
\hline $\begin{array}{c}\text { Court of } \\
\text { Makasar }\end{array}$ & 1 & 1 & & 2 \\
\hline $\begin{array}{c}\text { Court of } \\
\text { Medan }\end{array}$ & & & & & 2 \\
\hline $\begin{array}{c}\text { Court of } \\
\text { Bandar } \\
\text { Lampung }\end{array}$ & & & & & \\
\hline $\begin{array}{c}\text { Court of } \\
\text { Mataram }\end{array}$ & & & & & \\
\hline
\end{tabular}


The above data shows the environmental disputes went to court during 2016 - 2020, and the Court of Jakarta has the highest environmental causes than the Court of Bandar Lampung, Mataram, Makassar. Court of Bandar Lampung, there is no environmental case between 2016-2019; this is possible since maybe there is no environmental lawsuit.

The substance of the law relates to absolute competence, court position, judges, parties, type of lawsuit, type of compensation, sanctions (administrative penal sanctions and administrative sanctions), execution body to supervise, possibility to appeal or cassation. The substance of law has to be clear and easy to understand for everyone because it regulates the procedural law for environment disputes, including forestry. There should be some deviant principles of court's procedural as used to be in Act Number 5 the Year 1986 of Administrative Court and its amendments because this is a special court with a special characteristic.

Environmental disputes file to court to cancel the decision issued by Government body or officer about environment permission, and it has a specific classification: things caused damage and pollute the environment, forestry. Court procedure follows Act Number 5 the Year 1986 of Administrative Court and its amendments, to conduct the court by a certified judge of the environmental case from Supreme Court.

The execution process of judge verdict in civil disputes are the losing party and bailiff, in criminal charges is a public prosecutor, and administrative disputes are defendant. The execution process in court becomes difficult because it depends on moral and legal obedience from the defendant.

Law enforcement of administrative environmental disputes in Court follows Article Number 116 of Act Number 5 the Year 1986 of Administrative Court and its amendments, that 60 (sixty days) after the judge verdict legally binding, the decree does not have legally binding anymore. Problems come when the judge verdict gives an order to revoke the object of dispute and issue the new decree, but the defendant does not execute the judicial verdict. The regulations are clear, so does the judge verdict, and it also relates to the culture of law.

The culture of law in the frame of law enforcement can be seen from the lack of legal obedience of government bodies or officers to enforce the judge verdict in administrative environment disputes. On the other side, the characteristic of criminal charges, as ultimum remedium, thus it is necessary to make new regulation of environment disputes by developing administrative penal sanction. Lack of legal obedience is influenced by the resource of the environment; the more they abandon the judge verdict, the worst damage to the environment will come. There should be a criminal charge for those whomsoever does not fulfil a sentence by judge verdict. In the future environmental court has to develop administrative penal sanctions, to give deterrent effect to the defendant.

In case number 178/G/2015/ PTUN.Big Administrative Court in Bandung has cancelled the Regent's decree of liquid waste permission and strengthened by Supreme Court judge verdict number 187/K/TUN/LH/2017, and the Regent has cancelled the decree. On the other side, they had issued new permission, which did not come with procedures to adjust to disposal of liquid waste of Plaintiff [9]. The enforcement of environmental law is not only limited to how judicial action is executed, but the implementation and enforce environmental regulation is also significant [10]. The difficulties in implementing judge verdict of environmental cases have to think more about the urgency to build an environmental court. 


\subsection{Citizen Lawsuit in Environmental Protection}

There are 3 (three) types to put lawsuit, i.e., by government and local government, public, and NGO in environmental, as regulated in Article 90, 91 and 92 of Environmental Act. At the same time, each has different characteristics and shows the public participatory, awareness, responsibility to protect the environment. As regulated in Article Number 91 of Environmental Act, public rights to file class-action if there is the similarity of fact, legal basis or demand between representatives and members, as a legal basis to make citizen lawsuit. An administrative lawsuit can be filed based on Article Number 93 of Environmental Act, and it has the benefit that cancellation of decree gave impact to stop the activities. Thus it can not hold any longer neither damage the environment and the aim is to stop the environmental pollution [11].

Article Number 93 of the Environmental Act stated that everyone could file the lawsuit to Court when the government's body or officer issues the decree to the activity, which is compulsory to have an environmental impact analysis documents or documents of effort in managing the environment and environmental monitoring effort (UKL -UPL) or environment permission, but it is not supported with related documents for each activity. The procedures in the Courtroom follows the regulations in Act Number 5 the Year 1986 of Administrative Court and its amendments. As stated in Environmental Act, that environmental disputes mean disputes between parties arise caused by potential activity and/or impact on the environment. Referring to Court, there are no specific regulations to investigate an environmental dispute based on Court's regulations.

The first environmental dispute Number 008 / G/ 1994/PTUN.Jkt was put in Jakarta Administrative Court between Walhi, the Foundation for Population and Environment Studies Forum, Environmental Law Development Foundation as Plaintiff against President of The Republic of Indonesia; the object was Presidential Decree Number 42 of 1994 concerning Loan Aid originating from the Reforestation to PT.IPTN [2]. After this lawsuit, followed with others in different regions and object of disputes.

In Indonesia, based on regulation, a lawsuit put to the Court is an individual lawsuit, NGO's lawsuit and class action. The procedure to put the lawsuit in Court has to obey the Administration Procedural Act; every lawsuit that comes to Court have the main charge is the cancellation of the decree. In Court, public litigation advocacy only recognized for NGOs's and class action, after Act Number 30 the Year 2014 of Government Administration legalized, it is possible to put citizen lawsuit, as an anticipate to avoid overlapping absolute competence between general and administrative Court when litigating the public litigation disputes, which actually comes into administrative law especially administrative law [12].

In comparison, in 2018, there were two citizens lawsuits put in the different continents, first was filed in Oregon, USA, and the second was filed in Dutch Court, and the main object was cutting off gas emission which caused global warming. The Haque Court of Appeal regulated that preservation of a stable climate system is a fundamental right and ordered the Dutch Government to fulfil promises of making sharp cuts in greenhouse gas emissions. In Oregon, the lawsuit asks the government to create a national remedial plan to phase out fossil fuel emissions and draw down excess atmospheric $\mathrm{CO} 2$ and to stabilize the climate system and protect the vital resources of the environment where Plaintiff and future generations will depend. The Dutch and U.S government have argued that climate change is a global problem and no country can fix it, so the national court should not get involved. Both lawsuits raise issues globally about the role and competence of the court to hold governments around the world to account when they fail to act on their pledges to limit greenhouse gas emissions [13].

Citizen lawsuit mostly comes in common law system and use for environmental disputes, while in Indonesia it is rarely citizen lawsuit put for environmental disputes 
especially in Court. Citizen lawsuit of resolve smog had been settled in General Court of Pekanbaru, Riau, the important point is the government-issued policy for the environment to settled smog cases for Riau and other regions in Indonesia [14]. Citizen lawsuit usually goes to General Court to settle; it is rarely going to Court, it can be said that practically citizen lawsuit is accepted in general Court. Regulation of Supreme Court of Republic of Indonesia (PERMA) Number 1 the Year 2002 about Procedure of Class Action regulates about the formal requirements, procedural of class action lawsuit more leads to General Court than to Court.

A citizen lawsuit is a lawsuit proposed by a citizen against the government because they do not fulfil the obligations to the citizen; Plaintiff only shows the citizenship, it is not necessary to prove the legal standing or as the losing party. Citizen lawsuit makes for a public interest, not for the personal neither group and against the government since they are negligent in fulfilling their task and responsibility to the welfare of the citizen [15]. Government has an obligation to serve the public. Thus while making a decision or decree has to consider wisely the interests, needs of the public, not only prior to development. When they neglect their duty, it is possible to make a citizen lawsuit, using the legal process.

In Australia, it is regulated that everyone may institute the proceeding; this has means whether every single person or legal entity, citizen or personal suit are possible to make a lawsuit. This is in line with India; it is possible for everyone to make a lawsuit besides the organization legal standing. In the US, besides organization lawsuits, everyone is entitled to make environmental offences. Referring to the above comparison, Nommy Siahaan proposes it is necessary and urgent to regulate that civil lawsuit is possible to implement due to aims of protection of environment [16]. Considering the existing condition of environmental damage and the development, this idea should have positive feedback, with applying several terms to make regulation of citizen lawsuit.

The distinction between common and civil law, at this time, may not be appropriate for some purposes, especially when it is about the fulfilment of environmental human rights. Article $28 \mathrm{H}$ of Constitution of 1945 as the legal basis for everyone to get a good environment and healthy life, and should be understood in wide perspectives, such as the needs of a good environment as a basic principle for everyone, so it is important to us to get it and obtain with the right procedure, by the court, or other procedure.

Citizen lawsuit as one type of lawsuit should be considered to be implemented in Indonesia because restrictions of lawsuit give effect to environment's human rights, i.e. not fulfilled the substance of Article $28 \mathrm{H}$ of Constitution of 1945. The procedure of citizen lawsuit of environment disputes in Indonesia is not regulated; it is come out in practice in general court only. Second, based on intra-generational concept, it is our responsibility to keep the availability of environmental for next-generation, third, the conservation of the environment is important to keep the sustainability of the environment.

Supreme Court Number 1 the Year 2002 of Class Action Procedure released before Environmental Act legalized, and focused on General Court so that only ask for indemnity caused by development. It can't ask to cancel the government's decree, which is also important to stop the development which caused the environmental damages. Even though they get indemnity but the development still continues; it does not mean anything because the essential point is to stop the development.

Referring to Dworkin's theory, the right to equal treatment is the right of same distribution of things and chances, while rights to treatment as an equal means rights to have the same concern and respect in political decision-making. While Khuen's states that the right to equal treatment is distributive justice, and rights to treatment are as equal as procedural justice. Procedural justice focuses on the fair decision-making process, not the result of decision-making, including the public participatory in decision-making, right to 
sue, rights of information. [17] Each generation has the right to a healthy environment; it is our responsibility to ensure it will be useful for intra-generation, while procedural justice is a way to protect and maintain the environment as possible.

Citizen lawsuit is a way to control the legal action of government by the cancellation of government's decree to Court. The possibility to make citizen lawsuits to Court also gives more chances for the public to get their healthy environment rights. Moreover, it has more access to justice for environmental justice. It is also appropriate to Sustainable Development Goals (SDG's), especially goals to good health and well-being, clean water and sanitation, affordable and clean energy, sustainable cities and communities, climate action, life below water, life on land, access to justice and partnerships for goals, it interconnected.

Access to justice in the frame of environmental justice has to develop through a legal process that constitutionally guarantees the rights of a healthy environment for citizens. The development of society, the law, is the determining factor to make new regulations of citizen lawsuits in Court. Citizen lawsuits as part of procedural justice and access to justice has to be integrated into related regulations to give legal certainty. Citizen lawsuit is one mechanism to give more access to justice to everyone to get the justice against government's negligence.

\section{Conclusion}

The urgency to make future environmental court is highly needed because law enforcement from administrative environment law is hard to enforce. It needs a special environmental court as a special court under Administrative Court also to develop administrative penal sanctions. The damage to the environment caused by development has to stop by cancelling the government's decree. The special environmental court needs an environment justice system that consists of the private, penal and administrative justice system, especially to conduct the damage of the environment. There have to be new regulations about the special environmental court, as the structure of law, and it has to be harmonized with relevant regulations. The substance of law consists of the procedure of court, judges, parties, sanctions and develop administrative penal sanctions. The importance of administrative penal sanction relates to the culture of the law of the defendant. The culture of law consists of the legal obedience of the defendant to implement the judge verdict without exception and has become a problem from time to time.

Rights of the healthy environment have to be implemented with giving an opportunity to put citizen lawsuit to Administrative Court; this also gives access to justice for a citizen to get procedural justice. Citizen lawsuit in environment disputes to Administrative Court has to be developed considering as public case advocacy due to modernization, globalization and damage of the environment. When there is no regulation in Indonesia concerning citizen lawsuits, it is a limitation for a citizen to get access to justice; on the other side, the right to a healthy environment is a constitutional right, so it has to be implemented in regulations. Besides giving access to justice, citizen lawsuits are also a way to achieve procedural justice.

\section{References}

[1] A. Fatah, Gugatan warga negara sebagai mekanisme pemenuhan hak asasi manusia dan hak konstitusional warga negara, Yuridika, 28(3), 293-303 (2013)

[2] A. Fatah, Citizen lawsuit in environmental cases, Lentera Huk, 6(2), 289-308 (2019) 
[3] M. Junef and M. Husain, Pembentukan pengadilan khusus lingkugan sebagai wujud tanggung jawab negara pada upaya keadilan ekologis (Establishment of environmental specific jurisdiction as a state responsibility for ecological justice efforts), J. Penelit. Huk. Jure, 21(1), 59-74 (2021)

[4] R. R. Kurniawan, Integrasi citizen lawsuit sebagai hak prosedural atas lingkungan hidup dalam dimensi HAM, Pagaruyuang Law J, 1(1), 92-109 (2017)

[5] Sudjana, Penerapan sistem hukum menurut lawrence $w$ friedman terhadap efektivitas perlindungan desain tata letak sirkuit terpadu berdasarkan undangundang nomor 32 tahun 2000, Al Amwal, 2(1), 78-94 (2019)

[6] B. Enderle and J. Neutzner, At a glance: Enforcement of environmental law in Germany, (2020, September), Retrieved from https://www.lexology.com/library/detail.aspx?g=6b058b80-efc1-432b-9d5dfb3d95549f74

[7] U. Bjällås, Experiences of Sweden environmental courts, J. Court Innov, 3(1), 178$184(2010)$

[8] J. D. Zhang, A thesis on the establishment of specialized environmental and resources courts in China, (2019)

[9] A. K. Sihombing, Penegakan hukum terhadap pencemaran lingkungan di Sungai Cikijing, Jawa Barat akibat aktivitas industri, J. Huk. Lingkung. Indones, 7(1), 98$117(2020)$

[10] I. V. Natalia, M. Priyanta, Law enforcement towards environmental damage and pollution caused by open-pit coal, Tarumanagara Law Rev, 1(1), 62-90 (2019)

[11] A. Efendi, Penyelesaian sengketa lingkungan melalui peradilan tata usaha negara, Perspektif, 18(1), 14-22 (2013)

[12] E. Simanjuntak, Perkara advokasi publik pasca berlakunya undang-undang administrasi pemerintahan (UU AP) public litigation advocacy after enactment of government administration law, J. Ius Kaji. Huk. dan Keadilan, 6(1), 14-33 (2018)

[13] F. Pearce, Can citizen lawsuit force government to act on climate change (2018, November), Retrieved from https://e360.yale.edu/features/can-citizen-lawsuitsforce-governments-to-act-on-climate-change

[14] M. Zulaeha, Mengatasi kabut asap melalui mekanisme citizen lawsuit, J. Huk. Lingkung. Indones, 3(1), 87-106 (2016)

[15] M. Abubakar, Hak mengajukan gugatan dalam sengketa lingkungan hidup, Kanun J. Ilmu Huk, 21(1), 93-108 (2019)

[16] N. H. T. Siahaan, Perkembangan legal standing dalam hukum lingkungan (Suatu analisis yuridis dalam public participatory untuk perlindungan lingkungan), Syiar Huk, 3(3), 232-244 (2011)

[17] A. G. Wibisana, Keadilan dalam satu (intra) generasi: Sebuah pengantar berdasarkan taksonomi keadilan lingkungan, Mimb. Huk, 29(2), 292 (2017) 